\title{
Fray Agustín de Jesús, o de Castro
}

\author{
Figura egregia de la Orden de san Agustín \\ y de la Iglesia lusitana
}

\section{UNA FIGURA EGREGIA}

Dos arzobispos, escogidos dentro de la familia agustiniana, rigieron sucesivamente durante cinco lustros los destinos de la diócesis de Braga durante uno de los períodos de mayor esplendor en la península ibérica. Fueron respectivamente Fray Agustín de Jesús, llamado también por el apellido de la familia Fray Agustín de Castro (1588-1609), y Fray Alejo de Meneses (1612-1617).

Esto escribe el P. Carlos Alonso en la presentación que hace a la publicación, en la revista Analecta Augustiniana ${ }^{1}$, de una Documentación inédita sobre el primero de los prelados citados.

Al tiempo de escribir sobre esta figura sobresaliente de la Iglesia lusitana, no podemos por menos de recordar la similar y paralela española: Fray Tomás de Villanueva. Al igual que el santo limosnero de los pobres y arzobispo de Valencia, a quien tanto estimaba y admiraba el emperador Carlos V, Fray Agustín de Castro gozará de la estima del malogrado rey luso don Sebastián; será también reformador de la Orden de San Agustín; gran bienhechor de la misma y de muchos necesitados; y lo mismo que aquél había sido el gran promotor e iniciador de las misiones agustinianas de Méjico y el que consiguió con su celo y ardor apostólico la primera barcada para la Nueva España, el arzobispo de Braga puede ser considerado con toda justicia como el verdadero fundador, promotor y bienhechor de las Misiones Agustinianas en la India.

Sobre este último aspecto, el P. Antonio del Rosario, O.P., en el Congreso de B. Vicente de Albufeira, celebrado el 2 de septiem-

1. Alonso, C., "Documenta'ción inédita sobre Fray Agustín de Jesús, OSA., Arzobispo de Braga", Analecta Augustiniana, vol. XXXIV (1971) 85. 
bre de 1967, presentó un trabajo titulado: Para a historia do Populo de Braga; y en él nos dice acerca del P. Agustín de Jesús lo siguiente: "Entre las figuras que componen el cuadro del mundo-vivencia de B. Vicente de San Antonio, quiero evocar un ermitaño de San Agustín que, sin haber salido de Europa, es un gran misionero de este Oriente que hoy tenemos delante de los ojos. Se llama D. Fray Agustín de Jesús y fue arzobispo y señor de Braga, Primado de las Españas" ?.

Este egregio arzobispo es ciertamente una de las figuras de más alta estatura moral en la serie de prelados que gobernaron la diócesis antes de él. Su recuerdo -prosigue el docto historiador agustino arriba citado- está todavía presente en varios lugares de la catedral de Braga, de la que él fue magnánimo restaurador, además de reformador de su cabildo con la publicación en 1600 de nuevos estatutos. Su recuerdo pervive en el palacio arzobispal, que él amplió, y en cuyos salones penden todavía los retratos de sus antecesores, mandados pintar por él.

De la diócesis fue, no sólo bienhechor, sino también un amante de sus glorias, ya que mandó recoger y coleccionar los documentos del pasado y escribir su historia.

En la ciudad le recuerda especialmente el magnífico Colegio del Populo, que domina una de las plazas más amplias y hermosas de la población y que, destinado hoy en día a servicios militares, ha sufrido interiormente no pocos daños, pero conserva en su exterior la misma imponencia y majestad de antaño. Este edificio es un testimonio elocuente de su amor a la familia religiosa que le educó.

En la iglesia del Populo de Braga, aneja al Colegio homónimo, se conserva todavía el sepulcro de este venerable arzobispo colocado a un lado del prebisterio frente por frente y en posición simétrica con el sepulcro de su hermano de hábito, amigo y sucesor en la sede arzobispal, el mencionado Fray Alejo de Meneses ${ }^{3}$.

\section{RELIGIOSO AGUSTINO}

Agustín de Jesús había nacido el 16 de octubre de 1537 en la

2. ANTONIo DEL Rosario, OP., "Para a historia do convento do Populo de Braga", Bracara Augusta, vol. XXIII (Braga 1969) 4.

3. Alonso, C., 1.c., 86. 
bella ciudad de Lisboa, y estudiado humanidades en la famosa y universitaria Coimbra. Su deseo, desde muchacho, fue el de ingresar en los franciscanos de esta última ciudad; pero no se vieron cumplidos por juzgarlo demasiado débil de salud para una vida tan austera y rigurosa como la que llevaban los hijos de San Francisco.

Nacido de ilustre cuna y criado hasta cierto punto con regalo ", buscó una Orden que pasaba por observante, pero que era menos rigurosa y más humana para acomodarse y adaptarse viniendo de aquel ambiente rico y distinguido. La Orden escogida fue la de San Agustín. $Y$ fue precisamente el Vble. Fray Luis de Montoya -el reformador de los agustinos de Portugal- el que recibió a nuestro postulante y el que le envió en seguida a Lisboa ${ }^{5}$.

Aquí, en el Convento de Ntra. Sra. de Gracia, emitió sus votos el 7 de junio de 1555, adoptando el nombre de Agustín de Jesús ${ }^{6}$. De lleno ya en la vida religiosa, tomó por modelo al citado maestro Montoya, y de este modo, bien pronto se hizo digno de ocupar los primeros puestos en su provincia religiosa.

Primeramente fue prior del convento de Villaviciosa; más tarde, rector del colegio de Coimbra; y ya en 1570 prior provincial, cargo que ocuparía por segunda vez en 1582.

En 1575 asistió como Definidor al Capítulo General de Roma, formando entonces los capitulares un concepto tan elevado de su persona, que fue uno de los escogidos para la reforma de las Constituciones en conformidad con las nuevas normas emanadas del Concilio de Trento.

\section{SUPERIOR Y REFORMADOR DE LA ORDEN}

Y en Roma se encontraba Fray Agustín de Jesús, ocupado todavía en la tarea apuntada, cuando el emperador Rodolfo II propu-

4. Cuando pocos meses antes de morir escriba un documento privado haciendo en él una donación de dinero a su sobrino Don Irmo. de Castro, el anciano arzobispo resaltará el linaje y limpieza de sangre y cuna de sus antepasados: (BRAGA, Arquivo distrital, Caixa 54, s.n. - copia-).

5. El Vble. Luis de Montoya fue enviado desde España a restaurar la Orden de San Agustín en Portugal consiguiendo unos frutos tan admirables que, bien pronto, aquella provincia dio de religiosos tan ejemplares como nuestro biográfiado y tuvo una vida tan floreciente como se desprende del hecho de contar con gran número de religiosos y de las misiones que van a tomar a su cargo en Ultramar.

6. En el siglo se llamaba Pedro de Castro. En adelante, todos le lla- 
so al Papa Gregorio XIII y al General de la Orden que nombraran al P. Agustín de Castro reformador de los conventos de Alemania. Pareció bien aquella proposición, y nuestro celoso agustino fue investido de amplios poderes y nombrado Vicario General de todos los conventos de aquella nación.

El citado dominico Antonio del Rosario nos dice, a este propósito, que el P. Castro llevó a cabo tan delicada misión con aplauso unánime de superiores y súbditos, evidenciando un raro talento para el gobierno eclesiástico ?.

De regreso a España, el rey Felipe II le encargó arreglara ciertas diferencias que habían surgido en la provincia agustiniana de Aragón. Poco más tarde, se le encomendaría la difícil papeleta de la división de la provincia de Castilla en el célebre Capítulo celebrado en Dueñas el año 1582. Se conservan algunos documentos sobre el particular. Uno de ellos en el Archivo Vaticano, por el que el Nuncio de su Santidad en Madrid escribe a 18 de julio del citado año a la Secretaría de Estado comunicando precisamente que el rey de España había, por fin, designado a Fray Agustín de Jesús, provincial de los agustinos de Portugal, para reformar la provincia y para el que solicita la patente del $\mathrm{Papa}^{8}$.

A su vez en el Archivo de Simancas existen sendas cartas, una del duque de Olivares al rey, en la que le comunica que había conseguido del General de la Orden en Roma comisión especial a favor de Fray Agustín de Castro para que dividiese los conventos de España en dos provincias, conforme a los deseos del monarca?.

La otra carta es del propio General de los agustinos, dirigida a Felipe II, en la cual le expresa su entera satisfacción por los trabajos llevados a cabo por Fray Agustín de Jesús en el desempeño de su cargo como Visitador. Por lo cual, le recomienda eficazmente al monarca ${ }^{10}$.

Fue en este momento cuando la provincia de Andalucía, que

marán Agustin; pero en cuanto al apellido, no debió prevalecer el religioso, toda vez que los cronistas le llaman indistintamente con éste o con el patronímico de Castro; y así lo haremos nosotros también.

7. ANTONIO DEL ROSARIo, I.c., 5.

8. ARCH. Vat., Nunz. Spagna, vol. 28, fol. 143.

9. La carta está fechada el 25 de octubre de 1582 (ARCH. GRAL. DE SitMANCAS, Estado, leg. 943, fol. 78).

10. Esta carta lleva la fecha posterior del 31 de enero de 1583 (ARcr. Gral. de Simancas, Estado, Leg. 944, fol. 41). 
había estado unida o separada, según los avatares de los tiempos, de la de Castilla, se independizó definitivamente de esta última.

De su actuación como superior mayor de los agustinos de Portugal se conservan por fortuna bastantes documentos que nos hablan de modo elocuente sobre el particular ${ }^{11}$. Uno de ellos es un "proyecto" de una información de Fray Agustín de Jesús al Papa San Pío $V$, en la que expone las razones por las que no debía obligarse a la provincia portuguesa a la observancia de una reciente bula de reforma publicada por el mismo Romano Pontífice.

A! parecer, y según el informe, la causa por la que el Papa había enviado la bula de reforma a la Orden de San Agustín es porque sabe que han entrado en ella algunos abusos, principalmente el vicio de la propiedad. Y como quiera que el tener propio los religiosos en particular va contra el voto de pobreza que han profesado y contra su regla, es causa muy justa para llevar a cabo dicha reforma.

Es claro -razona Fray Agustín de Jesús- que la bula de reforma atañe solamente a aquellas provincias en que se cometieron estos abusos y que no es intención del Papa el obligar a dicha reforma a aquellas comunidades donde se guardan con fidelidad los votos y existe una estricta observancia regular.

Ahora bien, consta claramente que la provincia de San Agustín de Portugal, por mandato del rey don Juan III, fue de nuevo reformada mucho más de lo que estaba antes por los padres Fray Francisco de Villafranca y fray Luis de Montoya; reforma que han seguido sus mayores y prelados con rigor y gran celo, estando muy lejos no sólo de tener entre sí propio y quebrantar los votos de la regia, mas ni siquiera otros muchos pequeños defectos; y en todos los capítulos provinciales y visitas se ha procurado aumentar los estatutos para la mayor conservación y dura y estrecha observancia y reforma.

Por todo lo cual, los padres agustinos de la provincia de Portugal desean enviar al Papa, a instancia del rey, un informe en el que conste, entre otras cosas: que el rey hizo reformar dicha pro-

11. Estos documentos están recogidos y publicados por el P. Carlos Alonso en el número citado arriba de Analecta Augustiniana. Desde aquí vaya nuestro más profundo agradecimiento al amigo y docto investigador agustiniano, hoy Postulador General de Causas de la Orden, residente en Roma. 
vincia mucho más de lo que estaba por el Vble. Fray Luis de Montoya y Fray Francisco de Villafranca; lo cual hace ya cuarenta años que están así, con mucha observancia, paz y ejemplo, siendo una de las más reformadas del reino; que por esta causa, el rey tiene a bien favorecer a esta Orden no viendo en ella la necesidad de nueva reforma; que Su Alteza sabe que ahora, después de la muerte de su reformador, resplandece en dicha provincia la observancia y se guarda con mucho mayor fervor yendo en aumento de día en día; que tienen como cierta información que muchas de las cosas que se manda en el breve de Su Santidad pueden alterar el régimen interno de las Comunidades, lo que en ningún modo pretende el Papa; que sabe Su Alteza que por esta causa y no por relajación los prelados de esta provincia piden su protección para que interceda ante Su Santidad le haga ver cómo viven aquellos religiosos.

Seguidamente el provincial de los agustinos escribe un informe más detallado para el señor Embajador de Portugal en Roma que debe entregar al Papa y ver en él más concretamente las cosas en que puede perjudicar a los religiosos agustinos con aquella bula de reforma ${ }^{12}$.

Fray Agustín de Castro poseía dotes admirables de consejero y guía de los religiosos. Por el año 1572 envía a doce misioneros a las regiones del Golfo de Guinea ${ }^{13}$. Desde Peña Firme escribe para ellos una especie de reglamento en el que, tomando como base el primer capítulo de la regla de San Agustín, les da unos consejos llenos de prudencia y de fervor apostólico. "En todas vuestras palabras - les dice-, pensamientos, obras y deseos apurad de tal manera vuestra intención que no busquéis más que la honra y beneplácito divino".

Por lo que al prójimo se refiere, que el amor a los hombres que trajo Dios a la tierra os lleve a Mina y todo cuanto hagáis -acon-

12. Fray Agustín de Jesús va exponiendo y examinando artículo por artículo de la mencionada bula. Muy inteligente y sagaz, demuestra los daños, desventajas y perjuicios que se seguirían a los agustinos de verse obligados a cumplirla. El documento está firmado con el autógrafo de Fr. Agustín de Jesús y lleva la fecha de 6 de septiembre de 1571, en el convento de Ntra. Sra. de Gracia de Lisboa (BRAGA, Arquivo distrital, Caixa 4.6, s.n.):

13. Este mismo año, como hemos de ver más adelante, es el que envia, también en número de doce, a los primeros misioneros de la India Oriental. 
seja el sabio prelado- para ganarlos y traerlos a Dios será nada en comparación de lo que El hizo para salvarnos... A esto sois llamados, a esto vais, a esto enderezáis toda vuestra vida, ocio y negocio, sabiendo que ya sólo vivís para vuestros prójimos, a los cuales habéis de amar en Dios, por Dios y para Dios. Honrad en todos la imagen del Creador y no consintáis en vuestros corazones displicencia de ninguno, mas socorred a todos en dulzura de caridad y mansedumbre de palabras. Id aparejados para soportar las enfermedades de todos y socorredlos en sus: necesidades, perdonando las: ofensas que os hicieren y generalmente usad con todos de piedad sin aceptación de personas.

Así es Fray Agustín de Jesús y de este modo aconseja a sus misioneros, a los cuales pide unión y caridad entre sí, sin que existan entre ellos riñas y discordias. Les pide también que estén despegados de sus propios pareceres para cumplir plenamente la voluntad de Dios. $Y$ para que la paz del Señor se pueda conservar más fácilmente en vuestros corazones -les dice- dejaos gobernar por el parecer y la obediencia de un mayor, el cual en este caso, sea el P. Gaspar de los Angeles, por mandato mío, vuestro superior hasta tanto que fuere revocado por aquel que tenga igual 0 mayor poder que yo.

Es admirable en los detalles a que desciende para el tenor de vida que han de llevar durante la travesía. Como quiera que ésta ha de tener lugar en tiempo de Cuaresma, deben ordenarse de manera que todos los días hagan una plática espiritual sobre el evangelio de feria y a cierta hora de la tarde una serie de oraciones con el canto de la salve a. Ntra. Señora.

En amaneciendo, y después que se hayan levantado, irán a dár los buenos días a todos, comenzando por el capitán, con el que se han de tener muchos cumplimientos. Deben exhortar a todos a que se confiesen durante la cuaresma. $Y$ cuidar de los enfermos con mucha caridad. Eviten los rencores y. las discordias haciendo que crezca: la concordia y el amor entre todos. Está seguro de que cuatro hermanos unidos en Cristo con un mismo querer bastan para convertir a toda la gentilidad; mientras que cuatrocientos divididos, no lograrían ni una sola conversión.

No se le escapa al prudente y sabio provincial ni un solo detalle y así les dice también que, en ausencia del superior, deben prestảr obediencia al religioso más antiguo. $Y$ si Dios quisiera llevarse 
consigo al citado Fray Gaspar de los Angeles, le sucederá con los mismos poderes y limitaciones Fray Pedro ${ }^{14}$; y muriendo entrambos, que entre a gobernar el más antiguo y éste haga las veces de superior ${ }^{15}$.

\section{FRAY AGUSTIN DE JESUS, PROTECTOR DE LA ORDEN}

Es otro de los aspectos a destacar de este ilustre hijo de San Agustín. Su protección la ejercerá precisamente desde su sede de Braga. Siendo ya arzobispo de esta diócesis, y en abril de 1590 dio un decreto por el que permitía, dentro de los límites de la misma diócesis, hacer colectas en favor del convento agustiniano de Ntra. Sra. de Gracia, de Lisboa, regulando el funcionamiento de las mismas. El decreto va dirigido a todos los abades, priores, rectores, vicarios, curas y capellanes de las iglesias del arzobispado de Braga. Les hace saber cómo se han dirigido a él el Prior y los demás religiosos del monasterio citado presentando el privilegio que les concedieran los reyes de Portugal de tener limosneros y procuradores que pudieran pedir limosnas en todo el reino para las obras de dicho monasterio. Les hace notar cómo los obispos de Braga, antecesores suyos, favorecieron siempre con las licencias necesarias a dichos religiosos.

$Y$ como quiera que tienen entendido que los mencionados procuradores, encargados de este oficio, no cumplen con su cometido, e incluso de las limosnas recogidas entregan una pequeña parte de las mismas al monasterio, muchas veces con grave escándalo, les ha parecido más conveniente para el servicio de Nuestro Señor y beneficio de la mencionada comunidad que el propio arzobispo provea directamente de modo que las limosnas de los fieles, sin escándalo ni engaño alguno, se empleasen en el servicio de dicha casa de nuestra Sra. de Gracia, que es el motivo por el que las entregan.

El arzobispo de Braga no disimula la obligación y devoción particular que tiene por el mencionado convento ${ }^{16}$ y drce que sus moradores son dignos de aquella ayuda, por sus letras y buen ejem-

14. El documento no nos da el apellido de este religioso.

15. Braga, Arquivo distrital, Caixa 46, s.n.

16. Uno de los motivos que aduce en favor de este afecto especial es el de haber profesado en dicho monasterio, como también el amor que tiene por aquellos hermanos con los cuales ha convivido bajo la misma regla. 
plo, que son de gran provecho para el pueblo cristiano, al mismo tiempo que le constaba estaban padeciendo muchas necesidades, y con las obras todavía por terminar.

No queriendo acudir a los procuradores oficiales, se conformaban con que en la diócesis de Braga se hiciera lo mismo que había ordenado en la suya el arzobispo de Lisboa. Por todo ello, el de Braga manda a los referidos rectores de iglesias que en el primer domingo después de recibir este decreto encomienden a sus feligreses que favorezcan con sus limosnas al mencionado monasterio.

Para evitar abusos, ordena que las limosnas sean recogidas por los rectores de las iglesias, los cuales harán una declaración jurada de que las entregarán al provisor eclesiástico de la diócesis o al vicario general al tiempo de enviar a recoger los santos óleos. El propio provisor o vicario las recibirá haciendo tambiến declaración jurada de que obran en su poder. El arzobispo encarga mucho a los vicarios generales de las comarcas que tengan cuidado cuando los curas fueren por los óleos, de preguntarles por las dichas limosnas. Finalmente, les encarga que no permitan que pidan en sus respectivas iglesias los mencionados procuradores ${ }^{17}$ en nombre de Ntra. Señora de Gracia ${ }^{18}$; antes, por el contrario, les recojan las limosnas que tuvieren pedidas y las entreguen igualmente ${ }^{19}$.

Dentro de este mismo capítulo y como protector de la Orden, en mayo de 1591 el arzobispo bracarense escribirá un breve reglamento para el empleo de una suma de dinero que él envía al mismo convento de Lisboa. Se trata de la cantidad de dos mil cruzados entregados en dos ocasiones, en 1580 los mil primeros y al año siguiente los otros mil, con el encargo de que el P. Provincial los enviara a las misiones de la India Oriental.

Nuestro inteligente prelado se da cuenta de los recelos y suspicacias que esto puede ocasionar entre los agustinos de Portugal ros".

17. El nombre que se da a éstos en portugués es el de "mampostei-

18. El privilegio que tenian los agustinos de Lisboa de pedir limosnas por todo el reino se fundaba en la cofradía de Ntra. Sra. de Gracia, radicada en aquel convento.

19. El decreto lleva todas las formas legales; está hecho ante notario público-apostólico y va sellado con el sello del propio arzobispo. De lo cual da fe su secretario el Doctor Sebastián de Alfaro (BRAGA, Arquivo distrital, Caixa 49, s.n.). 
y los misioneros de la India. Para evitarlos, en lo posible, da ciertas normas sobre cómo se puede enviar dicho dinero, y sale al paso de las dificultades que puedan presentarse, recomendando encarecidamente a los Padres del Definitorio del Capítulo Provincial que se celebra precisamente por estas mismas fechas, y también al monasterio de Gracia de Lisboa que trabajen con prudencia y celo en ordenar del modo más conveniente que los religiosos de la provincia de Portugal y los de la India de la misma Orden tengan correspondencia acerca de estas limosnas y de todas estas cosas de tanta devoción y provecho espiritual del prójimo, ocupándose de ello personas que no padezcan detrimento alguno en la religión.

Tanto el Provincial como los Definidores ${ }^{20}$, reunidos en el convento lisboeta, a cuatro de mayo de 1591, están de acuerdo en todo cuanto señala el arzobispo de Braga, por entender que en todo lo que en dicho reglamento se contiene se hace gran merced al convento de Gracia y la misma provincia de Portugal, aceptando de buen grado cuanto en el reglamento se manda y ordena ${ }^{21}$.

Este gran amor que el arzobispo de Braga tenía por la Orden le llevó en ocasiones a defender a algunos de sus hermanos de hábito. Como ocurrió en el caso de Fray Miguel de los Santos. En el mes de mayo de 1591 escribió una carta-testimonio, dirigida probablemente al rey de España ${ }^{22}$, en favor de este religioso. Fray Agustín de Jesús da fe y certifica que conoce a Fray Miguel de los Santos, religioso de la Orden de San Agustín, nacido de padres nobles, "sin raza de judío ni de moro", descendiente de abuelos españoles que emparentaban con el Gran Capitán, Gonzalo Fernández de Córdoba ${ }^{23}$. De la vida, costumbres, letras y valer del agustino puede dar mejor testimonio que ninguno, pues fueron ambos novicios,

20. Todos ellos firman el documento, encabezado por Fr. Dionisio de Jesús, que es el superior mayor.

21. BRAGA, Arquivo distrital, Caixa 49, s.n.

22. En el dorso del documento, entre varias anotaciones de diversas épocas, hay una que acaso sea contemporánea y que dice a la letra: "Para sua Magestade".

23. Al parecer, y según nos cuenta Fray Agustín de Jesús, el abuelo de Fray Miguel de los Santos mató en un desafío a un primo-hermano suyo; por lo que pasó a Portugal, fijando su residencia en Mira, del reino de Algarve. Vivió allí poco tiempo, y dejando dos hijos, el mayor de los cuales murió en Africa cuando se perdió Luis de Louriro, y el más mozo que fue el padre de nuestro agustino, se hizo terrateniente con la hacienda que su padre le había comprado, y se casó con una mujer honrada y de gente limpia, siendo muy conocido y querido de todos. 
profesos y sacerdotes casi al mismo tiempo: Estuvieron juntos en la casa de probación de Lisboa durante seis años, juntos acabaron el curso de Artes y juntos estudiaron teología en la universidad de Coimbra. Unas veces fue superior suyo, y, otras súbdito, como ocurre entre religiosos y según los cambios en los distintos capítulos provinciales. Por lo cual afirma y sostiene que Fray Miguel de los Santos, desde que entró en la Orden ${ }^{24}$ vivió siempre en ella con gran ejemplo de virtud y religión y fue siempre tenido, así de prelado como de súbdito, por un religioso de vida ejemplar, mostrando siempre tanta gravedad, autoridad y modestia en su modo de proceder, que sin haber sido superior de ningún convento, cosa nunca vista en esta orden, fue nombrado de común consentimiento prior Provincial. Y luego, en el siguiente capítulo prior del convento de Gracia de Lisboa, volviendo a ser elegido provincial en el siguiente; y lo hubiera sido en otros muchos de haberlo permitido las constituciones de la Orden.

Durante su mandato - dice Fray Agustín de Castro- fue honrado y estimado de todos los religiosos de la provincia, por sus muchas partes y buen gobierno. En cuanto a suficiencia, ya cuando entró en la Congregación venía tan buen humanista, que, siendo todavía novicio, le hicieron lector de latín. Es más, habiendo por este tiempo muy buenos discípulos, Fray. Miguel los aventajaba a todos; y así le hicieron en seguida lector de un curso de artes.

Fue tan excelente predicador y adquirió tal nombre y fama por todo el reino en poco tiempo, que el propio Fray Agustín de Jesús se vio obligado, siendo provincial, a traerlo al convento de Lisboa para predicar al rey Don Sebastián; lo que hizo con gran crédito y honra de nuestra religión.

Por este mismo tiempo la reina Doña Catalina pidió al capítulo provincial que dejara a Fray Miguel de los Santos como predicador suyo para consolarse en su viudez, y fue tan grato a esta señora, que, aparte las muchas mercedes que le hizo en vida, le dejó en su testamento sesenta mil reales, gracia de la que todavía goza la. provincia.

Fray Miguel de los Santos intervino y presidió reuniones de teología; y con tener mucha habilidad, fue siempre tan estudioso; que

24. Fray Miguel de los Santos entró en la Orden Agustiniana siendo ya persona mayor. 
con mucha razón llegó a ser tan docto como lo es -afirma el arzobispo- al presente. Ojalá que no perteneciera a mi religión -termina su brillante apología-, para de este modo poderme alargar mucho más; pero todo lo dicho es tan notorio, que ninguno me podría tener como parte interesada y no creerme ${ }^{25}$.

La protección del arzobispo de Braga por la Orden Agustiniana no se ciñó a los conventos y religiosos de Portugal. Allí donde su mano bienhechora pudiera mostrarse extendida, allí estaría también su generoso corazón. En este sentido es altamente elocuente lo que hizo por el convento de Burgos y su célebre Santo Cristo. En el tantas veces citado archivo bracarense se encuentra un Acta Notarial suscrita por Tomás de Romarete, escribano público del rey de España, de la ciudad de Burgos, el cual certifica y da fe que la lámpara que el señor arzobispo de Braga mandó y ordenó se hiciese para que ardiera y alumbrara en la capilla del Santo Cristo, que está en el monasterio de San Agustín, extramuros de la ciudad de Burgos ${ }^{26}$, se hizo y acabó por mano de Melchor Barasona Varón, platero, vecino de la misma ciudad, con quien se concertó la hiciese.

Dicha lámpara de plata -leemos en el documento- fue puesta en la capilla el día de la Santa Cruz de septiembre ${ }^{27}$, próximo pasado ${ }^{28}$, y en ella se alumbra al Santo Crucifijo.

Tomás de Romarete nos asegura que dicha lámpara de plata se pesó en presencia suya, y pesó veintisiete marcos, seis onzas y cinco ochavos de plata. Da fe de ello, a petición de Fray Felipe de Campo, estando presentes por testigos M.I.N. de Zavala y Francisco de Romarete, residentes los dos en la mencionada ciudad de Burgos ${ }^{29}$.

Sobre esta misma donación, junto con otras noticias que se

25. Fray Agustín de Jesús quiere dar a este testimonio toda la fuerza que pueda, y así le manda sellar con su sello propio y firmar por su secretario Sebastián de Alfaro. El documento lleva la fecha de 6 de mayo de 1591. De la propia mano del celoso prelado podemos leer en postdata: "y declaro que después de leer artes, leyó también teología en nuestro colegio de Coimbra" (BRAGA, Arquivo distrital, Caixa 50, s.n.).

26. El famoso Santo Cristo de Burgos, un dia perteneciente a los agustinos de aquella ciudad, tiene hoy su capilla en la catedral, donde es objeto de devoción popular.

27. La festividad de la Exaltación de la Santa Cruz se celebra el día 14 de septiembre.

28. El documento está fechado en Burgos a 29 de octubre de 1594 .

29. BRAGA, Arquivo distrital, Caixa 51, s.n. 
refieren al convento burgalés, da cuenta al arzobispo el P. Cristóbal de Santotis, en una carta que le escribe a cuatro de noviembre del citado 1594. Usando de la licencia que V.I.S. me dio -escribemandándome no dejase de avisarle de esta su casa y de los sucesos de ella, me atrevo a escribir ésta. La lámpara de V.I.S. se trajo a esta su casa la víspera de Nuestro Padre ${ }^{30}$ con que se honró la fiesta, y el día de la Cruz de septiembre se puso en el santo Crucifijo, donde perpetuamente arde. Es de tanta majestad, que en su comparación todas las lámparas de la santa capilla son muy pequeñas. La Infanta envió el velo o paño del Santo Crucifijo, muy rico; los brocados que Su Majestad prometió no han venido porque se mandaron hacer en Florencia. El coro aún no está acabado, aunque están echadas las bóvedas altas y bajas. Las sillas para él están dadas a hacer. El dormitorio anda en buenos términos y se están tomando las aguas. No será posible que estas obras se puedan acabar de aquí al Capítulo ni aun en mucho tiempo después. Lo peor es que, con lo mucho que el Prior ha trabajado, está cuartenario y con su enfermedad andan las obras más flojas de lo acostumbrado. $Y$ dejando el oficio tengo por muy cierto que las obras cesarán y aun mucha parte de lo hecho se perderá. Por el grande amor que V.I.S. tiene a esta su casa - prosigue el P. Santotis - le suplico, y conmigo le suplican todos los principales del convento, nos haga merced de pedir al P. General mande que el P. Maestro Fray Felipe de Campo sea reelecto al priorato de esta Casa, pues importa tanto para el bien de ella y pues es conforme a la Constitución.

La despedida no puede ser ni más respetuosa ni más encomiástica a la vez. Con esto conoceremos ser V.I.S. - dice el célebre agustino- ${ }^{31}$ el que da el ser, lustre y perfección a esta su casa. En la que todos, como verdaderos capellanes de V.I.S. rogaremos a Nuestro Señor cada día dé el aumento de salud y estado que puede y toda nuestra religión ha menester.

Hasta aquí llegaba, por un lado, la influencia que el arzobispo to.

30. La fiesta de San Agustin se celebra en la Iglesia el 28 de agos-

31. Fray Cristóbal de Santotis era natural de Burgos en cuyo convento profesó a primeros de abril de 1543. Después de cursar la carrera eclesiástica en su convento, el General de la Orden le concedió que pasara a Lovaina con el fin de ampliar sus estudios a expensas de su madre. Todavía en aquella Universidad, el mismo P. General le encarga que haga todos los posibles para recuperar el convento de Amberes. Más tar- 
de Braga tenía ante el P. General; y por otro, la confianza que lós religíosos habían puesto en él ${ }^{32}$. Precisamente será el P. General, Fray Andrés de Fivizzano, el que le escriba una carta elogiosa y en la que le da las gracias por la construcción del colegio del Populo de Braga, que acepta oficialmente para la provincia agustiniana de Portugal y para la Orden, exhortándole con todo fervor y afecto fraternal a que lleve la obra a feliz término ${ }^{33}$.

De la fundación de este colegio nos quedan abundantes pruebas y documentos en el citado Archivo distrital de Braga. El documento principal nos dice que, ante el notario general de Braga, Fray Agustín declara que tiene ordenado y determinado edificar y dotar un monasterio, en esta dicha ciudad, de la Orden del bienaventurado San Agustín, por entender ser servicio de Nuestro Señor y aumento de la religión cristiana y provecho espiritual de esta ciudad ${ }^{34}$.

La Provincia agustiniana de Portugal, por su parte, acepta la donación y dote del celoso prelado. Fue justamente en el capítulo provincial, celebrado el cuatro de mayo de 1596, donde se aceptaron las condiciones de fundación. El Colegio quedaba incorporado a la provincia y el contrato lo firman el Provincial y el propio arzobispo.

Para llevar a cabo aquella importante obra, el P. Agustín de Castro anexionó entonces varias iglesias al nuevo monasterio, con el fin de que aquellas fueran provistas de predicadores, por cuanto

de, en 1562, fue enviado como teólogo por la Orden al concilio de Trento, donde pronunció varias oraciones y tomó parte muy activa en los trabajos conciliares, especialmente en la formación del Catecismo.

El P. General Cristóbal Patavino, que le conoció en Trento le recomienda eficazmente a los superiores de la Provincia de Castilla, consiguiendo de los mismos que le nombraran Definidor para el Capítulo General que había de celebrarse en Milán el 20 de mayo de 1564.

De vuelta a España recibió una comisión de Felipe II que no dice en qué consistiera. Más tarde los españoles en Flandes le pidieron por predicador suyo y allí permaneció por diez años cumpliendo a satisfación su cometido. EI rey Felipe II deseó que volviera a Flandes, pero el P. Santotis consiguió, por mediación del Conde de Barajas, quedarse en el convento de Burgos. Renunció a cuantas dignidades le ofreciera el propio monarca y recogido en su convento se dedicó a la tarea de ordenar sus escritos y publicar bastantes de ellos. Murió el año 1611.

32. El documento lleva escrito al dorso: "A Don Fray Agustín de Jesús, Arzobispo y Señor de Braga, del Consejo del Rey, nuestro Señor". Está fechado en Burgos a 4 de noviembre de 1594, y se encuentra en el citado Archivo distrital de Braga, "papeis avulsos", s.n.

33. BRAGA, Arquivo distrital, Caixa 52, s.n.

34. A continuación se detallan la donación y dote que concede al monasterio en bienes y fincas inmuebles (Cf. ANTONIo DEL ROSARIo, 1.c., 7), 
era grande la necesidad que existía en ellas y muchos pueblos, sobre todo de la montaña, se pasaban muchos años sin poder escuchar la palabra de Dios por falta de sacerdotes que fueran a anunciársela.

El señor Arzobispo estaba verdaderamente ilusionado con aqueIla fundación y esperaba que de ella salieran muchos y buenos teólogos, que supliesen la falta de sacerdotes seculares. Por eso promocionó y patrocinó los estudios en el mismo colegio, alentando a los superiores a que fueran exigentes en este terreno.

En este mismo sentido suplicaba al P. Provincial que proveyera y mandase al menos dos religiosos lectores en teología para atender debidamente a los nuevos educandos, ya que las universidades a las que aquellos podrían acudir, como Coimbra; Salamanca y Evora quedaban lejos y muchas familias no contaban con medios para enviarlos a estudiar a las mismas.

Le pide "dos lectores de teología, de los más doctos que tenga la provincia para leer dos lecciones diarias en las aulas públicas a todo el clero y a todos los que quisieren asistir con el fin de que, en adelante, hubiera abundancia de predicadores de la palabra de Dios" ${ }^{35}$.

Cuatro años más tarde, el señor Arzobispo se hacía eco de este encargo y contrato, y daba gracias a Dios y a los religiosos agustinos por el gran provecho que estaba haciendo con estas dos cátedras de teología en todo el arzobispado de Braga.

$Y$ tal vida tomó aquel nuevo estudio, que se hicieron nuevas aulas $y$ acudieron muchos escolares a escuchar las lecciones de teología. Y lo que es más notable e importante para nuestro estudio, el P. Agustín de Castro se preocupó de que el colegio de Ntra. Sra. del Populo de Braga fuera escuela de misioneros para el Oriente.

De tal manera es esto así, que el citado P. Antonio del Rosario no duda en llamar a nuestro ilustre prelado "arzobispo misionero", por cuanto no sólo accedió gustoso a la petición del Provincial de los agustinos a que aquel colegio admitiese a sus jóvenes para prepararse en la futura labor misional, sino que estimuló y aplaudió en cuanto estuvo de su mano esta idea. No olvidemos que de él partió la idea de enviar misioneros a la India y que los doce primeros agus-

35. ANTONIO DEL ROSARIO, I.c., 8 . 
tinos portugueses fueron como escogidos por él, 10 mismo que hiciera el Señor con el grupo de los doce apóstoles.

Al Colegio de Ntra. Sra. del Populo de Braga, verdadera escuela de teología, se unieron como iglesias parroquiales, según deseo del celoso prelado, las cinco más cercanas y más necesitadas. Idea ésta que alabó más tarde Alejo de Meneses. Dicha unión de las cinco iglesias fue confirmada por un breve del Papa Gregorio XV, con fecha cuatro de febrero de $1623^{36}$.

\section{PRELADO DE LA IGLESIA DE PORTUGAL.}

El rey de España Felipe II estimaba de modo especial a Fray Agustín de Jesús. Por lo que no dudó en presentarlo el año 1587 para el arzobispado de Braga. Fue consagrado en el convento de Ntra. Sra. de Gracia de Lisboa el día 3 de enero de $1589^{37}$.

Con la dignidad de arzobispo de aquella iglesia metropolitana iba unida la de Primado de las Españas, y aún se le quiso honrar con el nombramiento de Virrey de Portugal, cargo que no quiso aceptar por no verse obligado a abandonar sus ovejas.

Fray Agustín de Castro fue, nos dicen todos, un celoso prelado y pastor, verdadero reformador en la línea tridentina. Como prueba de ello tenemos la celebración de dos sínodos y la elaboración de unas Constituciones, corrigiendo muchos abusos que se habian introducido en las cosas santas.

También nos dicen que, a imitación de Santo Tomás de Villanueva, fue sumamente compasivo con los pobres; atendiendo de modo especial a los enfermos de los hospitales. Cada año dotaba gran número de doncellas y daba grandes limosnas a los conventos de religiosas.

Dentro del palacio arzobispal mandó pintar en grandes lienzos a todos los predecesores en el gobierno de su diócesis, colocando

36. ARch. VAт., Secret. Brev., vol. 1668, fol. 411-12 y 418 v, respectivamente.

37. El P. LANTERI en su Eremi Sacrae, pone la consagración el día 3 de enero de 1598 y la presentación del rey Felipe II el 31 de diciembre de 1597, no advirtiendo que estas fechas consignadas en HerRera están corregidas en la fe de erratas, debiéndose leer las que hemos dado en el texto, es decir, las 1587 para la presentación y la de 1589 para su siguiente consagración(Vid. LaNTERI, Eremi Sacrae, vol. II, p. 176; ToMas HerreRA, Alphabetum Augustinianum, I, 26; GREgorio dE SANTIAgo Vela, Ensayo de una Biblioteca Iberoamericana, vol. I, 657). 
su retrato en los muros del mismo palacio ${ }^{38}$. En el año 1592 consagró su catedral colocando en el altar mayor de la misma preciosas reliquias. Fue igualmente perito en la liturgia y en todo lo que decía relación con las ceremonias religiosas; lo mismo que en canto coral, al que era muy aficionado, recordando sus dias de simple religioso.

Celó con tal fervor por la pureza de la fe, que, acompañado de Don Teutonio de Braganza, arzobispo de Evora y de Don Miguel de Castro, arzobispo de Lisboa, vino a Madrid con el fin de obtener el perdón general que pretendían los judíos, como más adelante hemos de ver.

Antonio del Rosario escribe, a este propósito que, una vez en Braga, estuvo siempre empeñado en los cuidados pastorales, atendiendo al patrimonio cultural de la iglesia bracarense. Promovió una historia eclesiástica de la diócesis; creó el registro general del archivo de la misma sede; dio orden para que se hiciera la antología, o colección de Cosas Memorables, de la iglesia de Braga; organizó la galería de retratos de los arzobispos, como hemos apuntado arriba; y, aparte reunir los sínodos de 1594 y 1606, de que ya hemos hecho mención, dio unos Estatutos al cabildo en el año $1600^{39}$; renovó la dedicación de la sede catedralicia y adornó ricamente la capilla del Santísimo Sacramento.

Los cuidados por su iglesia y por su clero fueron tales, que pensó también edificar un hospital-asilo para clérigos pobres, ancianos y enfermos. Tales y tantas obras realizó en la ciudad de Braga, que se llegó a decir en vida del propio arzobispo que "hizo de esta ciudad la verdadera Corte portuguesa", dándole incluso hasta plaza de toros.

De todo esto poseemos una abundante documentación en el citado Archivo distrital bracarense. Ya el doce de febrero de 1588 Fray Agustín de Corneto, vicario general de la Orden, envía una patente a Fray Agustín de Castro por la que se le permite aceptar el arzobispado de Braga, para el que había sido presentado por el rey Felipe II ${ }^{40}$.

38. Fray Agustín de Castro fue inmediato sucesor de los insignes prelados Juan Alfonso de Meneses y Fray Bartolomé de los Mártires.

39. Estos Estatutos son, seguramente, los mismos que el P. Gregorio de Santiago Vela llama, en su nota bibliográfica "Constituciones" (Cf. Ensayo..., I, 657).

40. BraGa, Arquivo distrital, Caixa 49, s.n. 
Como anécdota curiosa de estos primeros días del arzobispado de nuestro agustino, encontramos un acta notarial que firma Francisco Mucancio ${ }^{41}$, y que trata de la segunda entrega del palio arzobispal, en vista de que el primero había sido robado por los hugonotes justamente durante el traslado de Roma a Braga ${ }^{42}$.

De la toma de posesión nos enteramos por un documento, un acia notarial en que se nos declara que Don Francisco de Santa María, obispo auxiliar y titular de Fez, tomó posesión de la sede en nombre del arzobispo.

Fray Agustín de Jesús, encontrándose en su convento de Gracia de Lisboa, prestó juramento de fidelidad al Papa y a la sede apostólica a 11 de febrero de $1589^{43}$.

Ya en funciones de arzobispo y por los mismos días, Fray Agustín de Castro escribe una carta pidiendo dispensa al Papa Sixto V de la visita Ad limina en vista de que, ni habia recibido el palio, ni tampoco había visitado la diócesis para mejor informar sobre la misma. Comienza su escrito alabando la constitución por la que todos los obispos, en determinado tiempo, deben visitar, ya por sí mismos, ya por medio de Procuradores, al Santo Padre en Roma. Pero como quiera que no ha recibido el palio arzobispal y no ha tenido tiempo de visitar su diócesis para de ella dar cumplida cuenta al mismo Romano Pontífice; y como quiera que él aun no conoce a sus ovejas, ni éstas conocen a su pastor, piensa que la tal visita ad limina, que le ha sido comunicada por el Colector del Papa puede ser retrasada, para lo que pide respetuosamente dispensa de la misma.

41. Francisco Mucancio era, según leemos en el documento, un clérigo romano, doctor en Derecho Canónico, maestro de sagradas ceremonias y notario apostólico de la Santa Sede.

42. BRAGa, Arquivo distrital, Caixa 49, s.n.i. Sobre este asunto existe en el mismo Archivo un recibo del agente del rey católico en Roma, Antonio Pinto, por el que certifica haber recibido del comerciante portugués Juan Enriquez la cantidad de doscientos escudos de oro para despachar las bulas de Fray Agustín de Castro.

$\mathrm{Y}$ es precisamente en este documento donde nos enteramos por el mismo Antonio Pinto de cómo, tanto las letras por duplicado del nuevo arzobispo de Braga, como las del palio fueron despachadas por unos hugonotes de Francia que hacían el correo en el mes de septiembre próximo pasado (el documento lleva fecha de 20 de octubre de 1588), lo que nos confirma lo dicho en el texto. (BRAGA, Arquivo distrital, Caixa 49, s.n.1.).

43. El documento está hecho ante el notario Tomás de la Cruz, el cual da fe del mismo y lo refrenda con su sello notarial (ARCH. VAT. principi, vol. 46, fol. 304-305v). 
Fray Agustín de Jesús piensa, y así lo expone, que, dada la enorme extensión que tiene la diócesis de Braga, necesita por lo menos cuatro años para visitarla detenidamente y atender a sus problemas como ella se merece. Cita el ejemplo de sus antecesores Giraldo, Fructuoso y Martín, los cuales necesitaron todo este tiempo; tanto más él que se considera menos que aquellos -vigilantes pastores. Con todo, advierte que, como el más pequeño y humilde de los siervos de Su Santidad, está dispuesto a lo que éste mande sobre el particular ${ }^{44}$.

Efectivamente, con fecha doce de abril del mismo año, el Cardenal Montalto, secretario de Estado del Papa Sixto V, escribe a Fray Agustín de Jesús una carta por la que se le concede la solicitada dispensa. La carta resulta altamente elogiosa para el arzobispo de Braga, pues el Cardenal le dice que Su Santidad no duda de la buena voluntad del Prelado; tiene en cuenta las razones que expone y está seguro de que a su debido tiempo satisfará con creces aquella obligación. Alaba en el arzobispo la conciencia que tiene de su ministerio pastoral y le exhorta en el Señor a que continúe en la misma idea contando con la benevolencia del Augusto Pontífice el cual le desea buena salud y le envía la paz de Cristo junto con la Bendición Apostólica ${ }^{45}$.

El cuidado pastoral del arzobispo de Braga se extiende también a las religiosas de su diócesis. Y para que éstas estén mejor atendidas, nombra al obispo de Fez vicario suyo en este asunto ${ }^{46}$. El prelado bracarense tiene una gran confianza en "las letras, virtudes y celo" que posee el citado obispo Don Francisco de Santa María. Por eso le ha rogado con mucha instancia a que acepte el gobierno espiritual y temporal de todos los monasterios de monjas sometidos a la jurisdicción del arzobispado.

Don Francisco de Santa María, con el fin de ayudar y descargar de los muchos trabajos que tiene el arzobispo, aceptó de buen grado el dicho cargo. Por lo que Fray Agustín de Jesús le concede su autoridad para que provea los dichos monasterios y atienda a sus negocios conforme le parezca más conveniente para el servicio de Nuestro Señor y provecho espiritual y temporal de las hermanas.

44. ARCH. VAT., Nunz. Spagna, vol. 37, fol. 3 228-229.

45. IBID.; Nunz Portogallo, vol. 6, fol. 71 (copia).

46. Este nombramiento lo hace por decreto del 2 de julio de 1589. 
Le concede todo poder para visitarlas, mandando a las Madres Abadesas y a las demás religiosas de dichos monasterios que le obedezcan en todo y cumplan sus mandatos como si se tratara de su misma persona ${ }^{47}$.

\section{PRELADO DE PORTUGAL}

Fray Agustín de Jesús, como arzobispo de Braga y primado de las Españas, se vio obligado a relacionarse con frecuencia con Roma y con la corte española. Muchos fueron los asuntos en que se vio complicado y no le faltaron disgustos y días amargos debidos, a veces, a falsas acusaciones, y otras a torcidas interpretaciones en la Sede Apostólica.

Testimonio de todo esto son los documentos encontrados en el mismo Archivo Vaticano. Uno de ellos, por ejemplo, va escrito en correcto italiano y dirigido al Cardenal Aldobrandini y en el cual Fray Agustín de Castro se defiende hábilmente en una contienda con el arcediano Font'Arcada por un beneficio de aquel arcediano asignado a la diócesis de Braga ${ }^{48}$.

En otro documento veremos a Don José de Melo, agente del rey Felipe III en Roma para la corona de Portugal, que escribe al propio monarca defendiendo el recto proceder del arzobispo de Braga en la causa de una religiosa de Valença do Miño por nombre Isabel de la Visitación.

El agente Melo hace ver al monarca español la poca culpa que tuviera el arzobispo de Braga y la mucha que tuvo Francisco Pereyra de Castro en sacar de su monasterio a dicha religiosa. Es más, el arzobispo había procedido contra ella prendiéndola y condenándola por sus relaciones conforme constaba en las autos y presentándola un sumario de culpas.

Le dice también que el Papa había respondido que estaba satisfecho con esta justificación y que mandaría un Breve para agradecer al arzobispo lo bien que se comportó en este negocio ${ }^{49}$.

Una vez más veremos a nuestro Prelado y a su auxiliar, el ci-

47. BRAGA, Arquivo distrital, Caixa 49, s.n

48. ARch. VAT., Borghese, ser. III, vol. 63-A, fol. 440 .

49. Muge (Portugal), Biblioteca de la Marquesa de Cadaval, ms. KVI-22 (937) fol 27 (copia). 
tado obispo de Fez, haciendo un recurso al Consejo de Estado contra Martín López de Carvalho.

Al parecer, este recurso no fue bien visto en Roma; por lo que la Secretaría de Estado escribe a Mons. Caracciolo, enviándole un Memorial en el que se detalla el recurso de los mencionados prelados contra Martín López, proveedor de la iglesia parroquial de San Clemente, de la diócesis de Braga.

La Secretaría de Estado lo juzga "de pésimo ejemplo"; por lo que se le encarga que ponga remedio en aquella causa, obrando conforme a la justicia. Y por lo que toca al recurso, que reprenda duramente a los dos prelados, recordándoles que por razón de su oficio deben edificar y no destruir y hacerse reos con escándalo público de una culpa tan grave ${ }^{50}$.

Mas por encima de todo esto nos encontramos con el prelado celoso y santo, bienhechor de todo el mundo, y fiel hijo de la lglesia. Después de la Reforma y dividida Europa, atentos los Príncipes a sus intereses personales y nacionales, era muy dificil suscitar la idea de cruzada contra los turcos que, a pesar de la derrota de Lepanto, seguian siendo fuertes en el mar y amenazaban constantemente a la Cristiandad.

El sucesor de San Pío V, el Papa Gregorio XIII había conseguido movilizar de nuevo a los príncipes cristianos; pero los otomanos, muy reciente todavia Lepanto, no se atrevieron a presentar batalla. Ahora, en 1594, se muestran de nuevo amenazadores y el Papa Clemente VIII trata de reunir recursos para emprender nuevamente una cruzada contra el enemigo implacable de la Cristiandad. Por eso se decide a pedir ayuda económica a los prelados de la Iglesia de distintos puntos de Europa.

La carta que escribe al arzobispo de Braga, al mismo tiempo que es un exponente del peligro turco, indica bien a las claras el alto aprecio en que tiene al ilustre prelado portugués. El Papa señala de modo especial el peligro que corre el emperador Rodolfo II y todo el sacro imperio, al cual deben prestar ayuda los demás príncipes cristianos.

Por lo que a los obispos y demás prelados de la Iglesia se refiere, deben saber que la benignidad de Dios les ha concedido bie-

50. ARCh. VAT., Nunz. Portogallo, vol. 12, fol. 26. 
nes de este mundo para atender a las necesidades de los pobres, para redimir cautivos y para remediar otras necesidades que piden la caridad y la piedad.

Clemente VIII justifica plenamente la guerra contra los turcos y está seguro de que el arzobispo de Braga entenderá hasta qué punto es necesario reunir dinero para defender la fe y la libertad de los cristianos. En este sentido espera mucho del metropolitano de Portugal, pues conoce su celo y piedad y la gran devoción que tiene hacia la Santa Sede. Por lo que pondrá un gran empeño y hará cuanto esté de su parte por tan noble causa ${ }^{51}$.

Poco tiempo después, a 22 de abril del mismo año 1594, el Colector Biondi escribe desde Lisboa al Cardenal Aldobrandini dándole noticias acerca de la contribución del arzobispo de Braga para la Cruzada antiturca. Todavía no le puede dar noticias en concreto sobre la recaudación; pero sí le puede decir que el dicho arzobispo goza de un buen nombre y su iglesia es la más rica del reino, a excepción de la de Evora ${ }^{52}$.

Se suceden las cartas del mencionado colector al cardenal sobre el mismo asunto en los meses de abril y de mayo de 1595; en los de junio y agosto. En ellas parece que se advierte una cierta demora por parte del prelado bracarense y también del obispo de Evora.

Pero será el propio Fray Agustín de Jesús el que se dirija personalmente al Papa acusando recibo de la carta pontificia y prometiendo una ayuda para la cruzada contra el turco, a pesar de las obras que estaba realizando en la diócesis. La carta es hermosa y manifiesta unos sentimientos de amor y devoción por el Romano Pontífice verdaderamtne ejemplares. Al mismo tiempo nos ofrece el más claro testimonio del gran bienhechor que fue para su diócesis, sus feligreses y sus hermanos de hábito. Dice el arzobispo de Braga que, recibidas las Letras Apostólicas, tan llenas de amor paternal, benevolencia, celo y singular estudio para ayudar la causa cristiana, a duras penas pudo contener las lágrimas, y de tal manera penetraron y conmovieron su ánimo que, si en su mano estuvie-

51. ARch. VAT.; Epist. ad Principes, vol. 27, 82-84.

52. En la carta alude también a la ayuda que está prestando a los hermanos agustinos en las obras del monasterio en la misma Braga, lo que hace con largueza y generosidad (IBID., Nunz. Portogallo, vol. 10, fol. 76. 
ra, volaría al lado del Santo Padre para ofrecerle todos sus bienes y la misma vida con su sangre toda en auxilio de la Santa Sede y propagación de la religión cristiana. Es más, constituiría para él la máxima felicidad el prestar este auxilio sin atender al tiempo, edad y trabajo.

Es admirable con qué humildad le dice al Papa que todo cuanto tiene es suyo, no sólo para esta ocasión, sino también para cualquier otra que hubiere menester. De todo ello puede disponer con p.ena libertad.

Lo que más siente es que no puede ayudarle en cuanto desea, pues está gravado con muchas obras, como es la restauración de las casas pontificias que, por ser muy viejas, amenazaban ruina, careciendo de comodidad los muchos huéspedes que a ellas solían acudir por caer la ciudad de Braga dentro de la ruta jacobea. Al mismo tiempo estaba edificando un nuevo monasterio para las monjas de San Salvador de Viturino, de la Orden de San Benito, las cuales vivían en descampado, expuestas a mil peligros; por lo que ha creído conveniente trasladarlas a la ciudad.

Ha levantado, asimismo, un domicilio a modo de colegio para recoger y ayudar a los sacerdotes pobres, ancianos y enfermos. De igual modo está empeñado en la erección de un convento agustiniano en la misma ciudad de Braga, lo que cree muy necesario y al que se siente obligado como miembro que es de dicha Orden ${ }^{53}$.

Además de todas estas obras, está contribuyendo con una buena cantidad de cruzados como limosna a la Casa de misericordia; así como también otra cantidad no menos importante para el hospital de peregrınos de la ciudad. Se ha gastado mucho aınero en el ornato y fábrica de distintas iglesias de la ciudad; y todos los años emplea gran parte de su dinero en dotes para jóvenes huérfanas, y sustentación de los pobres, "cuyo número casi es infinito en la diócesis".

Por todas estas causas - le dice al Santo Padre- se encuentra en un estado en que no sólo no le puede enviar una cantidad notable, mas ni siquiera una módica ayuda de dinero. Sin embargo, procurará por todos los medios y en breve tiempo reunir los dos

53. En justificación de esta obra aduce que solamente existe un monasterio de hermanos mendicantes en toda la ciudad, que es el de los capuchinos, y está en los suburbios. 
mil cruzados y enviarlos al Patriarca subdelegado para que a su vez los mande a la Santa Sede.

A continuación insiste en la devoción y obediencia filial para con el Pontífice, y le da cuenta de los años que ha pasado dentro de la Orden de San Agustín; y cómo el Papa Gregorio XIII le había comisionado para la reforma de los agustinos en Alemania; así como también el rey Felipe II le había nombrado visitador y reformador general de la misma Orden para toda España ${ }^{54}$.

Pocos días más tarde, a mediados de septiembre de aquel 1595, el Colector Biondi escribía al Cardenal Aldobrandini acerca de la contribución del arzobispo de Braga para la cruzada antiturca. En esta carta, lo mismo que en la siguiente, con fecha del $23 \mathrm{del}$ mes citado, el Colector confirma cuanto ha escrito el propio arzobispo al Papa y la necesidad en que se encuentra, metido como está en las obras del convento agustiniano, y en remediar tantas necesidades como existen en la ciudad de Braga.

Confirma, asimismo, la promesa que le ha hecho de entregar en breve la cantidad de dos mil cruzados ${ }^{55}$. Todavía encontraremos más cartas sobre el mismo asunto. El 7 de octubre, Biondi escribe al Cardenal citado comunicándole que espera contar pronto con la cantidad prometida por el gran arzobispo de Braga. Pero a 28 del mismo mes le dice que el Prelado estaba indispuesto y que esto ha debido retrasar el envío de los dos mil cruzados ${ }^{56}$.

Por fin, a 4 de noviembre, le comunica que con esa misma fecha ha recibido la contribución del arzobispo ${ }^{57}$, y el 25 del mismo mes le dice, en otra carta, que le envía le remesa de dos mil cruzados portugueses, pero cambiados en escudos de moneda de Roma ${ }^{58}$. Por otro documento que lleva la fecha del 23 de diciembre sabemos que los dos mil cruzados del arzobispo de Braga debian pagarse en Roma por Simón Henríquez y por vía de Florencia ${ }^{59}$.

El Papa Clemente VIII enviará luego una breve carta a Fray

54. ARCH. VAT., Nunz. Spagna, vol. 41, fol. 171-173.

55. IBID., Nunz. Portogallo, vol. 10, fol. 206.

56. IBID., fol. 237.

57. IBID., fol. 259.

58. IBID., fol. 270.

59. En el mismo documento se inserta un autógrafo del Patriarca de Jerusalén, el cual afirma que con esta carta manda los dos mil cruzados que se debian pagar en Roma por Simón Henriquez (el apellido aquí aparece tachado $\mathrm{y}$ se escribe Rodriguez) por orden de Florencia del Banco de Kieci. (ARCH. VAT., Ibid., vol. 10, fol. 1292). 
Agustín de Castro agradeciendo aquel envío de dinero para la cruzada antiturca y deseándole toda suerte de bienes y felicidad ${ }^{60}$. Que este Romano Pontífice tuvo especial afecto por el arzobispo de Braga, lo comprueba la serie de cartas que le dirigió por distintos motivos. Ya hemos podido comprobar algo con ocasión de la campaña contra el turco. Sabemos también de las dificultades en que se encontraba el Prelado. El Papa es comprensivo y le escribe ha ciéndole ver que no debe preocuparse, pero que espera de su generosidad y benevolencia cumpla lo promtido ${ }^{61}$.

En el mes de octubre de 1596 recibe otra carta del Papa en que le recomienda vivamente a Ferrante Taberna, nuevo colector apostólico en Portugal. En el mismo mes y año le daba las gracias, como hemos visto arriba, por el envío del dinero para la cruzada. Más adelante, en mayo de 1598 el Papa escribe al arzobispo de Braga recomendándole a Decio Carafa, nuevo nuncio en España ${ }^{62}$.

Fray Agustín de Jesús tuvo que comunicarse también con la corte española, concretamente con el Duque de Lerma y por asuntos relacionados con "los nuevos cristianos". En una primera carta, fechada en Valladolid a 24 de junio de 1602, le escribe en nombre también de los arzobispos de Lisboa y de Evora acerca del tema aludido. Le pide que informe al Rey adecuadamente sobre el particular; y que no haga caso de las pretensiones de los dichos "cristianos nuevos", pues están fundadas en falsas informaciones y perjudiciales cautelas al santo proceder de la Inquisición. Es más, si Su Majestad lo desea, los tres prelados están dispuestos a informarle de todo y personalmente, ya que si antes no lo hicieron, fue por no interrumpir las vacaciones de los reyes en Aranjuez; pero ahora que están "más despacio" en San Lorenzo, bien los puede recibir ${ }^{63}$.

Dos semanas más tarde, el propio valido contestaba al arzobispo desde el real sitio de El Escorial, comunicándole cómo había dado cuenta al rey de su súplica; y que el monarca le había contestado, como otras veces que le ha hablado sobre este negocio: que si los arzobispos le habian enviado un memorial -documento que

60. La carta está escrita en Frascati, a 17 de octubre de 1596.

61. ARch. VAT., Epistolae ad Principes, vol. 27, fol. 344-345.

62. IBID., vol. 30 , fol. 85 .

63. IBID., Borghese, serie III, vol. 63-A, fol. 166. 
ha muchos días están esperando-, enseguida tomarian la consideración que requiere un negocio tan grave, como lo hará en llegando a sus manos.

Les encomienda, de parte del mismo monarca, que se vayan a sus respectivas iglesias, donde hacen mucha falta; y que si quieren encargar el asunto a alguna persona de confianza lo podrán hacer sin dificultad ${ }^{64}$.

El Arzobispo de Braga acusaría recibo de estas nuevas y, estando todavía en Valladolid, contesta al Duque de Lerma, a 9 de julio, con una breve y respetuosa carta en la que le expone que, pareciéndoles bien a los tres prelados portugueses las razones del monarca, conviene en que sea Martín González de Cámara el encargado de presentar los argumentos que les asisten en aquel delicado asunto.

Para Fray Agustín de Jesús es de tal importancia y de tal calidad, "que sólo por esta causa, en razón de leales vasallos, nos pudiéramos dar por obligados a hacer todas las instancias posibles para lo ser". Luego le pide al privado que les haga la merced de suplicar a Su Majestad "sea servido de no nos enviar de su real presencia desconsolados y sin respuesta, que de su grandeza y mucha cristiandad esperamos, pues no lo acostumbra a hacer a otras personas que no tienen pretensión tan justa y tan propia de la piedad de Su Majestad, como es ésta con que a él venimos y tenga por bien dejarse enteramente informar en este negocio, que si no fuera de tanta importancia y no tocara tanto a nuestra santa fe y al servicio de Su Majestad bien pudiéramos entender que no teníamos fuerzas y edad para hacer tan largo y trabajoso camino, con las demás incomodidades que padecemos" ${ }^{65}$.

Sobre este mismo asunto el Nuncio en España, D. Ginnasi, escribirá, a 17 de octubre del mismo año, al Cardenal Aldobrandini, diciéndole que por fin, los arzobispos de Lisboa y de Braga habian regresado a sus diócesis contentos y satisfechos después de haber

64. IBID., fol. 167.

65. A la cabeza del escrito leemos la siguiente nota: "Copia de la respuesta, etc." Se la enviaron con Martín González de Cámara, que vino al mismo negocio de los arzobispos, en nombre y por orden de todo el reino, y le suplicaron los arzobispos fuera a San Lorenzo y llevase un papel con algunas razones sobre este negocio y partió luego y aún no tienen respuesta de lo que hizo, y se duda de que hallase a $\mathbf{S}$. $\mathbf{M}$. en San Lorenzo, porque dicen que partiría de allí a los 25 de éste (ARch. VAr., Borghese, serie III, vol. 63-A, fol. 167 ). 
conseguido del rey la palabra de que no se trataría más del partido de los "nuevos cristianos" de Portugal ${ }^{66}$.

\section{PROTECTOR DE AMIGOS Y PARIENTES}

Quizá sea éste uno de los puntos oscuros en la brillante y luminosa biografía de Fray Agustín de Jesús. No se libró de la lacra nepotista, tan frecuente en aquella época; pero tenemos que decir en su haber que, a cuantas personas recomendó eran dignas del cargo que para ellas suplicaba.

Con fecha 10 de abril de 1590, el arzobispo de Braga escribe al General de la Orden de San Agustín, Egidio de la Presentación, pidiéndole que confiriese un beneficio sine cura a Don Carlos de Meneses, sobrino suyo, persona idónea para el mismo.

El beneficio que pide para Meneses pertenece a la Iglesia de Santa María de Moreira, en la región de Monçao y administración de Valença, dentro del propio arzobispado de Braga, que había quedado vacante por fallecimiento de Antonio de Abreu de Lima, último abad beneficiado que fue de la misma ${ }^{67}$.

Poco más adelante, el 25 de noviembre de 1592, nuestro insigne prelado escribe al Papa Clemente VIII pidiéndole un beneficio simple de la iglesia de San Cristóbal de Mondina para su pariente Don Carlos de Noronha.

El beneficio en cuestión pertenecía al arzobispado de Braga y el último poseedor había sido Pedro de Vasconcelos. Por lo que se refiere al nuevo candidato, familiar del arzobispo, es un joven de 21 años de edad, que había obtenido el grado de derecho con admiración de todos y calificación de summa cum laude. Era hijo legítimo de Antonio de Meneses y de Juana de Castro; familia honesta y pobre hasta el punto de que nada le podía ofrecer y había hecho los estudios a expensas del propio arzobispo ${ }^{68}$.

En este orden de cosas, Fray Agustín de Castro no se libra del nepotismo con el que no pudo terminar ni el concilio de Trento. Salvemos, una vez más, la dignidad de las personas escogidas. Es más, en el Archivo Vaticano existe un documento en que el arzobis-

66. ARCH. VAT., Nunz. Spagna, vol. 55, fol. 386 .

67. BRAGA, Arquivo distrital, Caixa 49, s.n.i.

68. ARCH. VAT., Nunz. Spagna, vol. 41, fol. 5 . 
po de Braga se justifica plenamente sobre un delicado asunto en materia beneficial contra Agustín Ribeiro, abad en la diócesis de Braga.

El arzobispo acusa recibo del documento que le ha enviado el cardenal Alberto, archiduque de Austria, y legado "a latere" del Papa para el reino de Portugal, donde se dicen cosas contra él y contra jueces seculares del rey sobre materia beneficial del citado Agustín Ribeiro. Hace patente la fidelidad con que ha servido siempre a Su Santidad, a la Iglesia y a la Orden de San Agustín en los distintos cargos que le han confiado. Por lo que ruega y suplica al Papa que rechace toda opinión equivocada que haya podido concebir sobre su obediencia a Roma. Es más, si por la declaración que ha hecho Rodrigo Lobato de Andrade, "escolástico de Valencia", creen que ha incurrido en culpa ${ }^{69}$, está dispuesto a hacer penitencia en ceniza y cilicio y cumplir cuanto se le mande desde Roma.

Entretanto, y para que quede enterado completamente el Papa de aquel asunto, enviará a Simón de Abreu, uno de sus cinco vicarios generales, a la ciudad eterna. A este personaje, varón docto y de muchas letras, recomienda y espera que sea escuchado por la $\mathrm{Cu}$ ria romana ${ }^{70}$.

En otro documento el arzobispo de Braga escribe al Cardenal Aldobrandini, Secretario de Estado del Papa, recomendándole al citado Simón de Abreu, procurador del arzobispo para la visita ad limina ${ }^{71}$.

Fray Agustín de Jesús, no sólo se ocupará de favorecer a la Orden Agustiniana y a sus familiares. Cuidará también con esmero y defenderá a los sacerdotes de su diócesis que reclamen su atención y se vean necesitados de su ayuda. En cierta ocasión se dirigirá al Papa, pidiendo, bajo ciertas condiciones, dispensa de la residencia en favor de Don Fernando Mergulonio, párroco de San Clemente, en la diócesis de Braga. El Arzobispo ha encontrado en este sacerdote el hombre que por su doctrina y virtud necesita para llevar adelante el cúmulo de asuntos que crece en número de día en día. Pero como tiene la iglesia parroquial de San Clemente, con la obligación de

69. El arzobispo de Braga declara que tanto él como sus auditores han obrado en este asunto conforme al Concilio de Trento.

70. ARCH. VAT., Nunz. Spagna, vol. 41, fol. 6-7.

71. IBID., vol. 41 , fol. 13 y 16 . 
atender personalmente a sus ovejas y no puede en conciencia al mismo tiempo dedicarse al oficio que le encomienda el prelado, es por lo que pide para él al Santo Padre que le exima de la residencia parroquial. Pero como, además, la iglesia citada no dista de la casa del arzobispo más de 24 mil pasos, el citado párroco puede muy bien atenderla en los días festivos, en cuaresma y adviento, dedicándole al prelado los días feriados ${ }^{72}$.

Una vez más veremos al arzobispo de Braga pidiendo al Papa una canonjía vacante de la propia catedral bracarense para su pariente Don Martín Alfonso de Melo, hombre ilustre de cuna, pero pobre de verdad ${ }^{73}$.

Ya muy anciano y pocos meses antes de morir, Fray Agustín de Jesús escribe un documento privado por el que hace una donación de dinero a su sobrino Don Irmo de Castro. Es un documento extenso en el que expone las razones que le mueven a aquella acción: el parentesco directo que le une con el beneficiado, como que es hijo de un hermano suyo, "el mayor de todos" y nieto de Don Fernando de Castro, padre del arzobispo. También suscribe las cláusulas y obligaciones que dicha donación lleva consigo ${ }^{74}$.

\section{FUNDADOR Y PROTECTOR DE LAS MISIONES AGUSTINIANAS EN LA INDIA}

Fray Agustín de Jesús tiene el mérito, como ya queda escrito arriba, de haber sido el primero en enviar misioneros agustinos a las colonias portuguesas de Oriente, con su centro en Goa, y desde aquí extendiéndose su influencia y su labor apostólica por Persia, Arabia, Georgia, China y la Conchinchina, formándose luego la llamada Congregación Agustiniana de la India Oriental.

De igual modo, trabajó y consiguió el que estos aguistinos portugueses penetraran en el Congo y Angola, desde donde pasaron más tarde a otras posesiones lusitanas en Africa.

Mañana, cuando se encuentre al frente del arzobispado de Braga y con el honroso título de Primado de las Españas, resultará ser el más entusiasta de todos los misioneros. Como Meneses, pero desde Europa, será el gran protector y bienhechor de las misiones, el

\footnotetext{
72. IBID., fol. 18-19.

73. IBID., fol. 37.

74. BRAGA, Arquivo distrital, Caixa 54, s.n.i. (copia).
} 
padre y consejero de todos aquellos esforzados que le escribirăn: y contárán al pormenor los éxitos y los fracasos, los ratos de alegría y las largas horas de tristeza, los trabajos y serias dificultades que van pasando tanto en la India como en Persia. Sobre el particular, en el Archivo distrital de Braga se conserva una documentación hermosa y de ṕrimera mano que confirma cuanto aquí venimos diciendo. Son una serie de cartas y de informes que envian los misioneros al celoso prelado, y en los que le dan cuenta detallada de aquel campo de labor espiritual y misionero ${ }^{75}$.

Comenzando por las mismas Actas del Definitorio de la Provincia agustiniana de Portugal, celebrado en la ciudad de Santarem, a 28 de octubre de 1572, y presidido por el Padre Agustín de Jesús, como provincial, vemos cómo es aquí cuando se nombran a los doce primeros misioneros que debian partir para la India ${ }^{76}$. En este definitorio se dan ya las normas, las primeras disposiciones para el gobierno del grupo misionero. Por este mismo documento sabemos que el infortunado rey Don Sebastián mandó se edificara a costa suya un convento en la ciudad de Ormuz, siendo nombrado, en principio, Prior del mismo Fray Antonio de Paixao, y como sucesor suyo Fray Simón de Jesús. Este definitorio ruega encarecidamente y manda al mismo Padre Paixao que trabaje cuanto pueda por dejar ordenada y comenzada, antes de partir para Ormuz, una casa de la Orden en Goa, siendo elegido para el cargo de superior de la misma el P. Egidio de la Presentación y por subprior el P. Manuel de la Cruz.

Vemos, asimismo, en este documento una nota escrita al dorso y por distinta mano, en la que se nos da cuenta que en esta misma reunión de Santarem se determinó que fuesen religiosos a la isla de Santo Tomé a fundar un monasterio según los deseos del prelado de aquel lugar. Igualmente se dispone que pasen misioneros a Mina, a ruegos insistentes del citado y malogrado rey Don Sebastián ${ }^{7}$.

75. Toda esta documentación ha sido recientemente publicada por el P. C. Alonso en la revista Analecta Augustiniana, 53 (1970).

76. Este Definitorio estaba formado por los religiosos siguientes: Fray Agustín de Jesús, Provincial; Fray Pedro de Villaviciosa, Definidor; Fray Sebastián Toscano, Definidor; Fray Diego de San Miguel, Definidor; Fray Antonio de Paixao, Definidor (Cf. C. Alonso, Nueva documentación, 312).

77. C. Alonso, Nueva documentación... 310-12. 
$Y$ es ahora cuando nos damos perfecta cuenta de lo que significaba para aquellas misiones el Padre Agustín de Jesús desde su sede de Braga o simplemente como superior mayor de todos ellos. Uno advierte en seguida que nuestro celoso prelado se convierte en el centro de todas aquellas inquietudes. Uno tras otro, superiores y súbditos, le van contando sus andanzas y correrias, la marcha de la nueva misión, las fundaciones de distintos lugares y plazas de las colonias portuguesas, los trabajos que tienen que sufrir, el progreso, en fin, del reino de Dios en las Indias Orientales ${ }^{78}$.

Así, el Padre Simón de Jesús ${ }^{79}$ le escribe desde la ciudad de Goa el 8 de noviembre de 1572, apenas han puesto los agustinos pie en la capital de la colonia. En esta carta describe admirablemente el viaje a la India, al tiempo que le da cuenta de los planes que tienen para la fundación del primer convento en la mencionada ciudad ${ }^{80}$.

Años más adelante - 1585 - será el Padre Pedro de Santa María el que le escriba desde Ormuz dándole noticias de varias fundaciones agustinianas en la India; deteniéndose de modo especial en las de Goa y Ormuz ${ }^{81}$.

Dos años más tarde, el Padre Luis del Paraíso, a la sazón vicario provincial, le envía una larga carta en la que, aparte contarle detalles sobre la marcha de la congregación, le dice cómo el obispo de Malaca le pide misioneros para Macaçar; le da algunas sugerencias sobre lo que se podría hacer $y$, finalmente, le da noticias sobre el Padre Pedro de la Cruz y el convento de Thana ${ }^{82}$.

Nuevamente volveremos a encontrar una carta, ésta del P. Jerónimo de la Cruz, dirigida al Sr. Arzobispo de Braga; carta que es un elogio tan sincero como ponderado y justo al Arzobispo Meneses, Primado de la India, por su beneficencia y por su celo; amén de otras noticias sobre la muerte de hidalgos portugueses en las leja-

78. Estas cartas constituyen de por si un documento precioso para conocer las Misiones Agustinianas en la India de fuente viva y de primera mano, que viene a completar y en ocasiones a corregir las crónicas.

79. No debemos confundir este religioso con el célebre Fray Simón de la Concepción, más conocido por Fray Simón de Morales.

80. BRAGa, Arquivo distrital, "papeis avulsos; cartas", s.n. En C. Alonso, Nueva documentación...; Analecta, 33 (1970) 312-14.

81. IBID., 320-23.

82. IBID., 323-26. 
nas colonias y de la tarea que el propio Jerónimo de la Cruz se trae entre manos ${ }^{83}$.

Comenzado ya el siglo XVII, el P. Pedro de la Cruz, vicario provincial, le da cuenta del gran fruto conseguido por los misioneros en las diversas casas de la nueva Congregación ${ }^{84}$. Este mismo religioso le escribirá de nuevo en diciembre de 1602 desde Goa poniéndole al corriente del estado de las Misiones, de los estudios ec'esiásticos que se realizan en el convento de Goa, descendiendo luego a detalles de envío de algunos presentes ${ }^{85}$.

Cuando el $P$. Jerónimo de la Cruz se encuentre misionando en Persia, le enviará una carta desde la misma Ispahan; y en ella le dará noticias sobre el P. Nicolás Melo y su viaje por Rusia ${ }^{86}$.

En esta correspondencia de los misioneros con el eximio promotor y bienhechor no podía faltar la del P. Antonio de Gouvea. Le escribe desde Goa a finales del año 1605; y en la relación hace mención de su viaje a Persia y de la ayuda económica que ha pedido al Papa ${ }^{87}$, al rey de España -Felipe III-, atreviéndose a hacer lo mismo con el generoso arzobispo para la fundación de un seminario de armenios en la capital del imperio persa ${ }^{88}$.

El mismo año y solamente cuatro días más tarde de la carta anterior -exactamente el 29 de diciembre-, será el $P$. Juan de la Rocha el que, con motivo de la llegada del P. Melchor de los Angeles de Persia y Armenia, le enviará noticias frescas de aquellas misiones que, a juzgar por lo que dice, lo están pasando bastante mal y con muchas dificultades. Al mismo tiempo, se queja de los superiores de Portugal al no proveer de misioneros el importante convento de Ormuz ${ }^{89}$.

Luego será el $P$. Domingo de la Trinidad el que reconozca, llana y sencillamente, que el $P$. Agustín tiene más méritos que ninguno para considerarse fundador y protector de las misiones agustinianas de la India, por muchos y justos títulos, "ya que Vuestra Se-

83. IBID., $340-42$.

84. IBID., $342-43$

85. IBID., $347-50$.

86. Es curioso observar cómo el P. Jerónimo de la Cruz, en una sencillez casi infantil, llega a enviarle algunas pruebas por escrito de sus progresos en el idioma persa.

87. Se sentaba a la razón en la silla de Pedro Paulo V, el antiguo cardenal Camilo Borghese.

88. BRAGA, Arquivo distrital, 1.c., 356-59

89. IBID., 359-61. 
ñoría - le dice - las ha plantado y edificado; las ha dado sus primeras leyes y estatutos y reglas de vivir con que ellas comenzaron a tener vida y con que se conservan hasta el día de hoy" ${ }^{30}$.

El año 1607, el P. Antonio de Gracia y su Definitorio en pleno ${ }^{91}$, le envian un largo y detallado informe sobre los éxitos del colegio del Pcpulo de Goa como centro de estudios; la importancia de la labor misionera llevada a cabo entre los armenios de Persia, y la ayuda que necesitan para el seminario de estos cristianos en la ciudad de Ispahan ${ }^{2}$. El P. Juan de la Rocha le habla del peligro que suponían las naves holandesas que recorrian todos aquellos mares de la India, así como también el adelanto de las obras de la nueva iglesia de Goa, y noticias alarmantes sobre el apostolado entre los armenios $₫ 3$.

El propio Arzobispo de Braga escribirá al rey de España, Felipe III, hacia el año $1600^{94}$, dándole cuenta de las misiones de Persia que con tanto afán promovía el Papa Clemente VIII, y cómo debian encargarse de ellas los agustinos como los más entendidos y preparados para aquella delicada e importante tarea en la iglesia ${ }^{95}$. En este documento interesante vemos cómo, efectivamente, fue el propio rey Don Sebastián el que, en 1572, llamó al P. Agustín de Jesús, entonces provincial, manifestándole el gran deseo que tenía de enviar religiosos a Ormuz para que predicasen el evangelio, confesaran y trataran de la conversión de los infieles. "Y me rogaba mucho - escribe textualmente- quisiese aceptar aquella empresa por ser de gran servicio de Dios y suyo, y no haber ninguna Orden en la India que la quisiese aceptar, ya que los Padres de la Compañía habían estado allí algunos años y por los inconvenientes de aquella tierra se habían vuelto para la India; y que lo mismo

90. IBID., 361.

91. El Definitorio estaba formado en aquel año, según constatamos, por los PP. Juan de Santiago de Jesús, Francisco de Purificación, Antonio de Gouvea y Juan Pinto; amén del P. Antonio de Gracia que era el Vicario Provincial.

92. BRAGA, Arquivo distrital, 1.c., 364-67.

93. Las noticias alarmantes se refieren al enfriamiento por parte del Sha en las relaciones con el rey de España y, por consiguiente, con los misioneros de Ispahan, a los que dijo palabras injuriosas, molesto como estaba por no acudir el príncipe cristiano en su ayuda contra el turco.

94. En el informe dirigido al rey no aparece fecha alguna; mas por lo que se dice en el mismo, debió escribirse el año 1600.

95. Braga, Arquivo distrital, 1,c., 344-46. 
habian hecho los Padres de Santo Domingo, después de haber estado misionando seis o siete años en aquel lugar" ${ }^{96}$.

El P. Agustín de Jesús resalta la generosidad y la heroicidad de los hijos de San Agustín al aceptar aquel ruego del monarca teniendo en cuenta que órdenes tan señaladas y tan misioneras como la Compañía y la de Predicadores se habian retirado de aquel campo de labor por las dificultades que presentaba. Por lo que, enterado de que ahora el rey de Persia pedía al de España y al Papa ministros del santo Evangelio, le ruega se digne concederle el favor de que sean agustinos por las muestras que han dado de su celo y laboriosidad $y$, también y sobre todo, por cuanto contaban ya con el monasterio de Ormuz a las mismas puertas de Persia.

Finalmente, como prelado que mira por la paz y el buen ejemplo que debe existir entre los distintos miembros del clero, le pide a) rey que le haga la merced de recordar y tomar buena nota de la gran inquietud que existe en aquellas colonias portuguesas entre la Orden de San Agustín y la citada de Santo Domingo a causa de las precedencias. Haría un gran servicio a Dios nuestro Señor y un gran favor a las citadas órdenes y a todo el reino - le dice - si rogara al Papa que confirme la alternativa del rey Don Sebastián, mandando cesar la ejecución de breves anteriores, por ser ésta la única forma de que hubiera quietud y no aquellos malos ejemplos y escándalos que de continuo se daban ${ }^{97}$.

\section{PUNTO FINAL}

El P. Agustín de Jesús, protector de la Orden y de las misiones agustinianas de la India, lumbrera de la iglesia lusitana, murió el 25 de noviembre de 1609, cuando contaba los 72 años de edad. El rey de España, Felipe III, que había escrito al celoso prelado el 29 de octubre de aquel mismo año, comunicándole el jubileo de Santiago de 1610, concedido por el Papa, y ordenándole que lo publicara en su diócesis, escribirá al deán y cabildo de Braga, en el mes de diciembre, acusando recibo de la comunicación de la noticia de la muerte del arzobispo. Manda entonces que gobiernen la dióce-

96. IBID., 344.

97. IBID., 346. 
sis, en to espiritual y temporal, según justicia hasta la nueva provisión ${ }^{98}$.

Como nota final a tan ejemplar biografía diremos que el P. Vela añade que, curioso investigador y aficionado a la historia, nuestro ilustre prelado editó el primer Concilio celebrado en Braga el año 413. Es autor, además, de las mencionadas Constituciones del arzobispado de Braga; como también de un Catálogo de Arzobispos de la misma diócesis; y de unas Noticias de los progresos que hizo en la visita a las provincias de Alemania ${ }^{59}$.

Teófilo Aparicro

98. IвID., Cartas, t. 3, n. 41.

99. Según Barbosa, compuso también un libro de misas en música, con el fin de imprimirlo: y otras obras excelentes del mismo carácter, cuyos títulos no se especifican (Cf. D. Machado BaRbosa, Biblioteca Lusitana, vol. I, p. 61 . 